\title{
Effect of Dietary Electrolyte Balance on Water Intake, Litter Moisture and Production of Broiler chicks at Pre-Starter and Starter Phases
}

\section{Ibukun Olukorede Popoola1*, Debola Olusegun Oshibanjo², Oluwabukola Rashidat Popoola1, Titilayo Adetola Okuneye ${ }^{1}$, Ibinabo Imuetinyan Ilaboya ${ }^{1}$, Eustace Ayemere Iyayi ${ }^{1}$}

\author{
${ }^{1}$ Department of Animal Science, University of Ibadan, Ibadan, Nigeria \\ ${ }^{2}$ Department of Animal Production, University of Jos, Jos, Nigeria \\ Email: *popoolaibukun@yahoo.com
}

How to cite this paper: Popoola, I.O., Oshibanjo, D.O., Popoola, O.R., Okuneye, T.A., Ilaboya, I.I. and Iyayi, E.A. (2019) Effect of Dietary Electrolyte Balance on Water Intake, Litter Moisture and Production of Broiler chicks at Pre-Starter and Starter Phases. Open Journal of Animal Sciences, 9, 472-480.

https://doi.org/10.4236/ojas.2019.94036

Received: August 9, 2019

Accepted: October 26, 2019

Published: October 29, 2019

Copyright $\odot 2019$ by author(s) and Scientific Research Publishing Inc. This work is licensed under the Creative Commons Attribution International License (CC BY 4.0).

http://creativecommons.org/licenses/by/4.0/ (c) (i) Open Access

\begin{abstract}
Underestimating the negative impacts of ammonia produced in litters of poultry birds raised under high temperature-humidity index is dangerous, as broiler chickens (BC) are sensitive to high ammonia concentrations which can result in blindness and overall decrease in productive performance. Hence, it is ideal to maintain litter moisture by optimizing the utilization of water by broiler chicks. The balance of acid-base in broilers could be enhanced by supplementing diets or water of $\mathrm{BC}$ under heat stress with electrolytes. However, electrolytes increase water intake and might affect litter quality. Therefore, effect of varying dietary electrolyte balance (DEB) on water intake (WI), litter moisture (LM) and productive performance of $\mathrm{BC}$ were investigated at pre-starter and starter phases using a total of three hundred, 1-day-old Arbor Acre chicks that were randomly allotted to six dietary treatments [210 $\left(\mathrm{T}_{1}\right), 240\left(\mathrm{~T}_{2}\right), 270\left(\mathrm{~T}_{3}\right), 300$ $\left(\mathrm{T}_{4}\right), 330\left(\mathrm{~T}_{5}\right)$ and $\left.360\left(\mathrm{~T}_{6}\right)\right] \mathrm{mEq} / \mathrm{Kg} \mathrm{DEB}$, in a completely randomised design. Birds were reared at pre-starter phase (PSP) of 0 - 14 days and starter phase (SP) of $14-21$ days, under the temperature-humidity index of $24.97-35.19$. Water intake and litter moisture were monitored. Data were analysed using descriptive statistics and ANOVA at $\alpha_{0.05}$. Water intake was enhanced at PSP and $\mathrm{SP}$ in birds on $360 \mathrm{mEq} / \mathrm{kg}$, but with increased litter moisture. However, a dietary electrolyte balance of $270 \mathrm{mEq} / \mathrm{kg}$ improved performances of broiler chicks at pre-starter and starter phases.
\end{abstract}

\section{Keywords}

Broilers, Electrolytes, Feed Conversion Ratio, Heat Stress, Homeostasis, Litter Moisture 


\section{Introduction}

Water is crucial in poultry nutrition, as it functions in metabolism, regulation of body temperature, transport of nutrients and excretion of waste materials [1]. [2] reported that it is an acceptable practice to daily monitor birds' water consumption, which gives an early indication of a health problem when water consumption is compared to the standard consumption expected. [3] reported that water consumption in birds can be affected by factors such as environmental conditions; feed and water quality, among others like external air humidity, type and management of a drinker system, age and weight of birds [4]. [5] reported that inadequate management practices in a poultry house leading to increased ammonia concentration in air often result in health problems including contact dermatitis, enteritis and respiratory diseases. [6] noted that drier poultry litter reduces the emission of ammonia into the environment, and this would help avoid environmental and animal welfare problems, with increasing economic profits as one of the end results. Feed ingredients may also affect the rate of water consumption and excretion [7]. However, [2] concluded that daily water consumption is a reliable indicator of broiler performance. Respiratory alkalosis is a product of heat stress, a condition of excess blood bicarbonate reacting with other ions such as sodium ion $\left(\mathrm{Na}^{+}\right)$, calcium ion $\left(\mathrm{Ca}^{2+}\right)$, magnesium ion $\left(\mathrm{Mg}^{2+}\right)$, and potassium ion $\left(\mathrm{K}^{+}\right)$before being eliminated [8]. Hence, maintenance of bird's acid-base balance is crucial for efficient performance under high temperature as suggested by [9]. Additional potassium and sodium are favorable for birds reared in heat stress environment, but also increases water intake. Therefore, this study aimed at assessing the effect of different dietary electrolyte balance and water intake on the feeding potential and excreta quality of broiler chicks reared under heat stress at pre-starter and starter phases.

\section{Materials and Methods}

The protocol for the experiment was reviewed and approved by the Institutional Animal Care and Use Committee through the Agricultural Biochemistry and Nutrition Unit of the Department of Animal Science, University of Ibadan, Nigeria. The study was carried out at the Teaching and Research Farm, University of Ibadan during the dry season with high environmental temperatures. A total of three hundred, 1-day-old Arbor Acre broiler chicks were randomly allotted to six treatments [mEq/Kg: $210\left(\mathrm{~T}_{1}\right), 240\left(\mathrm{~T}_{2}\right), 270\left(\mathrm{~T}_{3}\right), 300\left(\mathrm{~T}_{4}\right), 330\left(\mathrm{~T}_{5}\right), 360\left(\mathrm{~T}_{6}\right)$ DEB] with five replicate groups of ten birds each, in a completely randomized design (CRD). The gross compositions $(\mathrm{g} / \mathrm{Kg}$ ) of starter diets fed to the heat-stressed broiler chicks in each treatment group were shown in Table 1. The DEB was calculated using the equations derived by [10]. The derived equation of DEB is

$$
\sum \mathrm{DEB}=\sum\left(\mathrm{Na}^{+}+\mathrm{K}^{+}\right)-\sum \mathrm{Cl}^{-} \cdots[\mathrm{y}][\mathrm{c}]
$$

where $\Sigma \mathrm{DEB}=$ aggregate DEB; 
Table 1. Gross composition $(\mathrm{g} / \mathrm{Kg})$ of starter diets fed to heat-stressed broiler chicks.

\begin{tabular}{|c|c|c|c|c|c|c|}
\hline Ingredients & $\begin{array}{c}210 \\
\mathrm{mEq} / \mathrm{kg}\end{array}$ & $\begin{array}{c}240 \\
\mathrm{mEq} / \mathrm{kg}\end{array}$ & $\begin{array}{c}270 \\
\mathrm{mEq} / \mathrm{kg}\end{array}$ & $\begin{array}{c}300 \\
\mathrm{mEq} / \mathrm{kg}\end{array}$ & $\begin{array}{c}330 \\
\mathrm{mEq} / \mathrm{kg}\end{array}$ & $\begin{array}{c}360 \\
\mathrm{mEq} / \mathrm{kg}\end{array}$ \\
\hline Corn & 617.00 & 608.10 & 606.40 & 598.70 & 593.00 & 585.30 \\
\hline Soyabean meal & 292.00 & 292.00 & 292.00 & 292.00 & 292.00 & 292.00 \\
\hline Fish meal & 45.00 & 47.00 & 48.00 & 50.00 & 51.00 & 53.00 \\
\hline Soya oil & 12.00 & 16.00 & 17.00 & 20.00 & 22.00 & 25.00 \\
\hline Dicalcium phosphate & 18.00 & 18.00 & 18.00 & 18.00 & 18.00 & 18.00 \\
\hline Vitamin $\cdot$ mineral premix ${ }^{1}$ & 2.50 & 2.50 & 2.50 & 2.50 & 2.50 & 2.50 \\
\hline Limestone $^{2}$ & 9.00 & 9.00 & 6.00 & 6.00 & 6.00 & 6.00 \\
\hline DL-methionine & 1.00 & 1.00 & 1.00 & 1.00 & 1.00 & 1.00 \\
\hline L-lysine & 1.00 & 1.00 & 1.00 & 1.00 & 1.00 & 1.00 \\
\hline Salt & 2.50 & 2.50 & 2.50 & 2.50 & 2.50 & 2.50 \\
\hline Potasium Chloride $(\mathrm{KCl})$ & 0.00 & 1.00 & 2.00 & 3.00 & 4.00 & 5.00 \\
\hline Sodium bicarbonate $\left(\mathrm{NaHCO}_{3}\right)$ & 0.00 & 1.90 & 3.60 & 5.30 & 7.00 & 8.70 \\
\hline TOTAL & 1000.00 & 1000.00 & 1000.00 & 1000.00 & 1000.00 & 1000.00 \\
\hline \multicolumn{7}{|l|}{ Calculated analysis } \\
\hline Crude protein, $\mathrm{g} / \mathrm{kg}$ & 225.01 & 225.69 & 226.26 & 227.05 & 227.29 & 228.07 \\
\hline $\mathrm{ME}, \mathrm{kcal} / \mathrm{kg}$ & 3007.13 & 3016.56 & 3022.08 & 3027.13 & 3027.65 & 3032.70 \\
\hline Calcium, g/kg & 10.66 & 10.76 & 9.67 & 9.77 & 9.82 & 9.92 \\
\hline Non-phytate $P, g / k g$ & 4.28 & 4.27 & 4.27 & 4.27 & 4.27 & 4.26 \\
\hline
\end{tabular}

${ }^{1}$ Composition of premix per kg of diet: Vitamin A, 12,500 I.U; Vitamin D3, 2500 I.U; Vitamin E, 40 mg; Vitamin K3, 2 mg; Vitamin B1, 3 mg; Vitamin B2, $5.5 \mathrm{mg}$; Niacin, $55 \mathrm{mg}$; Calcium pantothenate, $11.5 \mathrm{mg}$; Vitamin B6, $5 \mathrm{mg}$; Vitamin B12, $0.025 \mathrm{mg}$; choline chloride, $500 \mathrm{mg}$; Folic acid, $1 \mathrm{mg}$; Biotin, $0.08 \mathrm{mg}$; Manganese, 120 mg; Iron,100 mg; Zinc, 80 mg; copper, 8.5 mg; Iodine, 1.5 mg; Cobalt, 0.3 mg; Selenium, $0.12 \mathrm{mg}$; Antioxidant, $120 \mathrm{mg} .{ }^{2}$ Limestone contains $38 \%$ calcium.

$[y]=$ mineral sources;

[c] = other macro ions (Ca, Mg, P, S etc) held constant.

Aggregate DEB = Inherent DEB in rations + DEB in Electrolyte sources.

A total of 38 pens were used in this study in order to measure water intake in heat-stressed broiler chickens as described by the authors. This methodology was premised on the assumptions that the study of water kinetics is important in agricultural research and helps to solve critical issues affecting efficient broiler chicken productivity. To adequately measure actual water intake in birds, 8 pens were randomly isolated. Plastic drinkers of the same size, shape and thickness were put in 38 pens. Equal volume and height of water in the drinkers were maintained daily in the 38 pens. This method is premised on the theories propounded by Pascal's principle of pressure and principle of thermal expansivity of liquids [11].

Daily evaporative rate $(\mathrm{DER})=\frac{\sum(V \alpha-V \gamma / V \alpha)}{n}$ 
where $V \alpha=$ Initial volume of water supplied in the drinker at the evaporation chamber;

$V \gamma=$ Final volume of water left in the drinker at the evaporation chamber;

$n=$ Number of isolated pens (8).

$$
\text { Actual water intake }=\left(V_{1}-V_{2}\right) \times \mathrm{DER}
$$

where $V_{1}=$ Initial volume of water supplied to birds;

$V_{2}=$ volume left over.

Maximum and minimum average ambient temperature and relative humidity of the pen were monitored on a daily basis using a digital hydro thermometer. Assay was conducted in each diet for sodium and potassium (Flame spectrophotometer), and chloride (titration) [12] as shown in Table 2. Feed intake was calculated from the difference between supplied feed and feed left in each pen. Feed weighing was performed on the same dates the birds were weighed. Feed conversion was calculated as the ratio between weight of total feed intake and weight gain within the period in each pen and was adjusted for mortality.

Litter moisture content was evaluated weekly. For each replicate pen, four samples of around $500 \mathrm{~g}$ of litter were collected at random locations following equal distances with later homogenization to make a single sample per pen. Analysis for litter dry matter was performed by oven drying using the forced ventilation method at $55 \pm 5 \mathrm{C}$ for $72 \mathrm{~h}$ and evaluation by weight difference. Data obtained were subjected to descriptive statistics and analysis of variance using SAS package [13]. Means for treatments in the analysis of variance were compared using Duncan Multiple Range Test and based on probability level of 0.05.

\section{Results and Discussion}

At prestarter phase, significant $(\mathrm{p}<0.05)$ differences in dry matter intake of birds fed different DEB were observed. Birds on $330 \mathrm{mEq} / \mathrm{Kg}$ DEB had higher ( $\mathrm{p}$ $<0.05)$ dry matter (431.70) intake compared to birds on $270(377.77) \mathrm{mEq} / \mathrm{Kg}$ DEB. However, at 14 to 21 days, feed intake of birds was not significantly ( $\mathrm{p}>$

Table 2. Analysed nutrients in experimental diets fed to broiler chicks at pre-starter and starter phases.

\begin{tabular}{cccccccc}
\hline \multirow{2}{*}{ PERIODS } & NUTRIENTS (\%) & \multicolumn{7}{c}{ Diets $(\mathrm{mEq} / \mathrm{kg})$} \\
\cline { 3 - 7 } & 210 & 240 & 270 & 300 & 330 & 360 \\
\hline \multirow{3}{*}{$0-21 \mathrm{~d}$} & Crude protein & 22.90 & 22.95 & 23.10 & 22.93 & 22.79 & 22.89 \\
& Crude fat & 5.29 & 5.26 & 5.44 & 5.54 & 5.46 & 5.66 \\
& Calcium & 10.09 & 10.16 & 10.36 & 10.06 & 10.20 & 10.25 \\
& Phosphorus & 8.02 & 8.03 & 8.09 & 8.12 & 8.13 & 8.16 \\
& Sodium & 1.40 & 2.20 & 2.92 & 3.63 & 4.33 & 5.05 \\
& Potassium & 8.16 & 8.65 & 9.18 & 9.73 & 10.21 & 10.66 \\
& Chloride & 2.32 & 2.81 & 3.27 & 3.75 & 4.28 & 4.77 \\
\hline
\end{tabular}


$0.05)$ affected by different DEB treatments. The observed differences in feed intake could be attributed to intake of water, solely driven by dietary salt concentrations. At 0 to 21 days, analysis of variance showed no significant $(p>0.05)$ differences in feed intake and DM intake of birds fed different DEB treatments. This result has shown that birds 'appetite was not enhanced by dietary electrolyte balance at starter phase. These findings disagree with the report of [14] who stated that regardless of ambient temperatures, increasing DEB stimulated feed intake, which could be the result of increasing $\mathrm{Na}^{+}$levels in diets $(0.15 \%$ to $0.45 \%)$. [15] reported that the weight of birds, when assessed at $42 \mathrm{~d}$, decreased when DEB was lower than $180 \mathrm{mEq} / \mathrm{kg}$ and higher than $300 \mathrm{mEq} / \mathrm{kg}$ while an optimal electrolyte balance was found for feeds at 250 to $300 \mathrm{mEq} / \mathrm{kg}$. [16] investigated the effect of feeds containing DEB in different ratios with varying calcium levels of $1.38 \%$ and $0.95 \%$, and noted that the worst and the best weight gains were achieved when the DEB was 174 and $215 \mathrm{mEq} / \mathrm{kg}$, respectively. In the current study, the body weight (BW) of birds on different dietary treatments was not significantly $(\mathrm{p}>0.05)$ affected at pre-starter and starter phases. However, at 0 - $21 \mathrm{~d}$ period, the BW of birds on 330, 270 and 240 DEB were significantly $(\mathrm{P}<$ $0.05)$ higher compared to other dietary treatments. The lowest $(\mathrm{p}<0.05) \mathrm{BW}$ was observed in birds on 210 and $360 \mathrm{mEq} / \mathrm{kg}$ DEB. This result agrees with the findings of [17] and [18] who established an optimal DEB for modern broiler strains to be between 246 and $315 \mathrm{mEq} / \mathrm{Kg}$ at starter phase. [19] reported that optimal chick growth performance, when fed purified diets, was achieved using DEB $\left(\mathrm{Na}^{+}+\mathrm{K}^{+}-\mathrm{Cl}^{-}\right)$of around $250 \mathrm{mEq} / \mathrm{kg}$. The observed body weight gain (BWG) of birds in the current study was not significantly ( $p>0.05$ ) affected by different DEB treatments at pre-starter phase. However, at 0 to 21 days, significant $(p>0.05)$ differences were observed in BWG of birds fed different dietary treatments. Birds on $330 \mathrm{mEq} / \mathrm{Kg}$ DEB had higher $(\mathrm{p}<0.05)$ BWG compared to 210 and $360 \mathrm{mEq} / \mathrm{Kg}$ DEB. Similar BWG values were observed in birds on 240, 270,300 and $330 \mathrm{mEq} / \mathrm{Kg}$ DEB. [20] noted that electrolyte manipulation significantly influenced the best electrolyte balance for broilers.

At 0 to $14 \mathrm{~d}$, water intake of birds was affected $(\mathrm{p}<0.05)$ by different DEB treatments. It was observed that birds on $240,270,300$ and $330 \mathrm{mEq} / \mathrm{Kg}$ DEB had similar water intake, but higher $(\mathrm{p}>0.05)$ compared to those on 210 and $360 \mathrm{mEq} / \mathrm{kg}$ at prestarter phase. During 15 to $21 \mathrm{~d}$, there were no significant ( $\mathrm{p}>$ 0.05 ) differences observed in water intake of birds on 240,270, 300, 330, and 360 $\mathrm{mEq} / \mathrm{Kg} \mathrm{DEB}$, but differed significantly $(\mathrm{P}<0.05)$ compared to birds on 210 $\mathrm{mEq} / \mathrm{kg}$ DEB. It was observed that birds on $360(821.89 \mathrm{~mL}) \mathrm{mEq} / \mathrm{Kg} \mathrm{DEB}$ had significantly $(\mathrm{p}<0.05)$ higher water intake compared to birds on other dietary treatments at 0 to 21 days. It is well known that water is an essential nutrient in poultry nutrition, especially during hot environmental temperature. [21] reported that increased survivability during heat stress has been shown to correlate with water consumption. The increase in water consumption is advantageous to birds because it increases the amount of heat dissipated by evaporative cooling 
through the respiratory tract [22]. In the current study, the effect of different DEB on mortality of chicks ( 0 - 21 days) showed no significant $(\mathrm{p}>0.05)$ differences. This result shows that heat-stressed birds at starter phase can ionically manipulate their survivability through systemic intake of water. Also, the effect of different DEB on water intake of broiler chickens at starter phase showed significant $(\mathrm{p}<0.05)$ differences. It was observed that birds on 270, 240 and 300 $\mathrm{mEq} / \mathrm{Kg}$ DEB had reduced intake of water when compared to birds fed other dietary treatments. This result has shown that the intake of water was dependent on dietary cation and anion balance inside the birds. Also, the excretion of excess metabolic acids plus water was not dependent on volume of water taken in by the birds. According to [23], dissipation of more than $80 \%$ of the heat produced through evaporative cooling has showcased the importance of increased water consumption in heat-stressed broilers. Water consumption depends on the age of the bird, ambient and water temperatures, physiological state, water $\mathrm{pH}$, levels of macro-nutrients in feed, amount and types of salt added in feed and water. The increase in water consumption benefits the birds by acting as heat receptor and also increases the amount of heat dissipated per breath [22].

The litter moisture content of birds fed varying DEB treatments at pre-starter and starter phases is presented in Table 3. Increased $(\mathrm{p}<0.05)$ litter moisture was observed in birds on higher DEB values of 330 (35.06) and 360 (41.52) $\mathrm{mEq} / \mathrm{Kg}$ compared to other treatments. However, there were no significant $(\mathrm{p}>$ $0.05)$ differences in litter moisture content of birds on 240 and $270 \mathrm{mEq} / \mathrm{Kg}$ DEB. At 15 to $21 \mathrm{~d}$ (Max: $38^{\circ} \mathrm{C} \pm 2{ }^{\circ} \mathrm{C}$, Min: $23^{\circ} \mathrm{C} \pm 2^{\circ} \mathrm{C}$ ), significant $(\mathrm{p}<0.05)$ differences were observed in litter moisture content of birds on varying levels of DEB. Birds on $360 \mathrm{mEq} / \mathrm{Kg}$ had higher $(\mathrm{p}<0.05)$ litter moisture content than birds on other treatments. There were no differences $(p>0.05)$ observed in litter moisture content of birds on 240 and $300 \mathrm{mEq} / \mathrm{Kg}$ DEB. Birds on $210 \mathrm{mEq} / \mathrm{Kg}$ DEB had the lowest $(\mathrm{p}<0.05)$ litter moisture content at 15 to $21 \mathrm{~d}$. Results obtained from current study on litter moisture content revealed that different DEB affected litter quality at starter phase. The lowest litter moisture was observed for birds on $210 \mathrm{mEq} / \mathrm{Kg}$ DEB when compared to other dietary treatments. This result corroborates the findings of [24] that any increase in the dietary $\mathrm{Na}$ and $\mathrm{K}$ intake enhanced water consumption and excreta moisture. Also, that increased water consumption caused by greater DEB values had a direct impact on litter moisture and also reduces the rectal temperatures in birds. [14] observed linear increase in water intake of heat-stressed broilers with increasing DEB levels in the diets and with bird's age.

\section{Implication}

A dietary electrolyte balance of $270 \mathrm{mEq} / \mathrm{kg}$ improved performances of broiler chicks at pre-starter and starter phases. Water intake was enhanced at pre-starter and starter phases in birds on $360 \mathrm{mEq} / \mathrm{kg}$ but with higher litter moisture. 
Table 3. Effect of varying dietary electrolyte balance on performance of heat-stressed broiler chicks at prestarter and starter phases.

\begin{tabular}{|c|c|c|c|c|c|c|c|c|}
\hline Periods & $\begin{array}{c}\mathrm{DEB} \\
\mathrm{mEq} / \mathrm{Kg}\end{array}$ & $\begin{array}{c}\text { DMI } \\
\text { (g/bird) }\end{array}$ & $\begin{array}{c}\text { BW } \\
\text { (g/bird) }\end{array}$ & $\begin{array}{l}\text { BWG } \\
(\mathrm{g})\end{array}$ & $\begin{array}{l}\text { FCR } \\
(\mathrm{g} / \mathrm{g})\end{array}$ & $\begin{array}{c}\text { WI } \\
(\mathrm{mL} / \mathrm{bird} / \text { day })\end{array}$ & $\begin{array}{c}\text { Litter } \\
\text { moisture } \\
(\%)\end{array}$ & $\begin{array}{c}\text { Mortality } \\
(\%)\end{array}$ \\
\hline \multirow{6}{*}{$0-14 d$} & 210 & $412.63^{\mathrm{ab}}$ & 319.60 & 283.40 & $1.56^{\mathrm{a}}$ & $235.63^{c}$ & $14.56^{\mathrm{e}}$ & 0.00 \\
\hline & 240 & $405.07^{\mathrm{ab}}$ & 331.24 & 294.66 & $1.48^{\mathrm{ab}}$ & $261.93^{\mathrm{b}}$ & $23.65^{\mathrm{d}}$ & 0.00 \\
\hline & 270 & $377.77^{\mathrm{b}}$ & 332.16 & 295.80 & $1.38^{\mathrm{b}}$ & $265.18^{\mathrm{b}}$ & $26.06^{\mathrm{d}}$ & 0.00 \\
\hline & 300 & $388.58^{\mathrm{b}}$ & 339.39 & 303.17 & $1.43^{\mathrm{ab}}$ & $265.69^{\mathrm{b}}$ & $30.33^{c}$ & 2.00 \\
\hline & 330 & $431.70^{\mathrm{a}}$ & 333.40 & 297.10 & $1.55^{\mathrm{a}}$ & $280.67^{\mathrm{ab}}$ & $35.06^{\mathrm{b}}$ & 0.00 \\
\hline & 360 & $388.32^{\mathrm{b}}$ & 320.14 & 284.54 & $1.51^{\mathrm{ab}}$ & $297.16^{\mathrm{a}}$ & $41.52^{\mathrm{a}}$ & 0.00 \\
\hline SEM & & 12.59 & 10.99 & 10.96 & 0.05 & 7.67 & 1.00 & 0.82 \\
\hline p Value & & 0.06 & 0.77 & 0.78 & 0.11 & 0.00 & 0.00 & 0.44 \\
\hline \multirow{6}{*}{$15-21 d$} & 210 & 394.79 & 319.60 & 309.54 & $1.38^{\mathrm{ab}}$ & $449.32^{\mathrm{b}}$ & $40.43^{\mathrm{d}}$ & 0.00 \\
\hline & 240 & 389.78 & 331.24 & 328.56 & $1.29^{\mathrm{ab}}$ & $498.95^{\mathrm{a}}$ & $50.72^{\mathrm{c}}$ & 0.00 \\
\hline & 270 & 407.04 & 332.16 & 341.28 & $1.30^{\mathrm{ab}}$ & $501.98^{\mathrm{a}}$ & $60.52^{\mathrm{b}}$ & 0.00 \\
\hline & 300 & 406.56 & 339.39 & 317.11 & $1.43^{\mathrm{a}}$ & $507.48^{\mathrm{a}}$ & $53.32^{c}$ & 0.00 \\
\hline & 330 & 392.52 & 333.40 & 346.28 & $1.21^{\mathrm{b}}$ & $506.55^{\mathrm{a}}$ & $63.44^{\mathrm{b}}$ & 0.00 \\
\hline & 360 & 380.53 & 320.14 & 304.64 & $1.39^{\mathrm{ab}}$ & $524.72^{\mathrm{a}}$ & $73.27^{\mathrm{a}}$ & 0.00 \\
\hline SEM & & 11.45 & 10.99 & 14.43 & 0.06 & 10.51 & 2.46 & 0.00 \\
\hline p Value & & 0.56 & 0.77 & 0.26 & 0.18 & 0.00 & 0.00 & 0.00 \\
\hline \multirow{6}{*}{$0-21 d$} & 210 & 807.41 & $629.14^{\mathrm{c}}$ & $592.94^{\mathrm{b}}$ & $1.47^{\mathrm{a}}$ & $684.95^{\mathrm{c}}$ & - & 0.00 \\
\hline & 240 & 794.84 & $659.80^{\mathrm{ab}}$ & $623.22^{\mathrm{ab}}$ & $1.38^{\mathrm{ab}}$ & $760.88^{\mathrm{b}}$ & - & 0.00 \\
\hline & 270 & 784.81 & $673.44^{\mathrm{a}}$ & $637.08^{\mathrm{ab}}$ & $1.34^{\mathrm{b}}$ & $767.15^{\mathrm{b}}$ & - & 0.00 \\
\hline & 300 & 778.46 & $656.50^{\mathrm{b}}$ & $620.28^{\mathrm{ab}}$ & $1.38^{\mathrm{ab}}$ & $773.17^{\mathrm{b}}$ & - & 2.00 \\
\hline & 330 & 824.22 & $679.68^{\mathrm{a}}$ & $643.38^{\mathrm{a}}$ & $1.37^{\mathrm{ab}}$ & $787.22^{\mathrm{b}}$ & - & 0.00 \\
\hline & 360 & 768.85 & $625.78^{c}$ & $590.18^{\mathrm{b}}$ & $1.45^{\mathrm{ab}}$ & $821.89^{a}$ & - & 0.00 \\
\hline SEM & & 20.29 & 14.66 & 14.715 & 0.04 & 15.31 & - & 0.82 \\
\hline p Value & & 0.44 & 0.08 & 0.08 & 0.11 & 0.00 & - & 0.44 \\
\hline
\end{tabular}

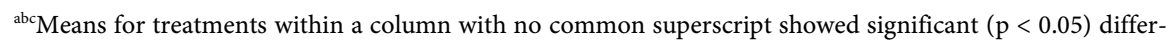
ences using DMRT, DMI-dry matter intake, BW—body weight, BWG—body weight gain, FCR—feed conversion ratio, DEB - dietary electrolyte balance, $\mathrm{p}$ value - probability, SEM-standard error of mean.

\section{Acknowledgements}

The profound moral and financial supports of Engr. and Mrs Popoola are hereby acknowledged.

\section{Conflicts of Interest}

The authors declare no conflicts of interest regarding the publication of this paper. 


\section{References}

[1] Jafari, R.A., Fazlara, A. and Govahi, M. (2006) An Investigation into Salmonella and Faecal Coliform Contamination of Drinking Water in Broiler Farms in Iran. International Journal of Poultry Science, 5, 491-493. https://doi.org/10.3923/ijps.2006.491.493

[2] Defra (2002) Meat Chickens and Breeding Chickens. Code of Recommendations for the Welfare of Livestock. 72-75.

[3] Manning, L., Chadd, S.A. and Barnes, R.N. (2007) Water Consumption in Broiler Chicken: A Welfare Indicator. World s Poultry Science Journal, 63, 63-71. https://doi.org/10.1017/S0043933907001274

[4] Broadbent, L. and Pattison, M. (2003) Winter Ventilation-Minimum Ventilation for Good Air Quality. Poultry World.

[5] Ekstrand, C. (1993) Effect of Stocking Density on the Health, Behaviour and Productivity of Broilers. Swedish Facility of Agricultural Science Report 32, Shaka.

[6] Ferguson, N.S., Gates, R.S. and Taraba, J.L. (1998) The Effect of Dietary Protein and Phosphorus on Ammonia Concentration and Litter Composition in Broilers. Poultry Science, 77, 1085-1093. https://doi.org/10.1093/ps/77.8.1085

[7] Francesch, M. and Brufau, J. (2004) Nutritional Factors Affecting Excreta/Litter Moisture and Quality. World s Poultry Science Journal, 60, 64-75. https://doi.org/10.1079/WPS20035

[8] Molero, C. (2007) Nutritional Solutions to Heat Stress. International Poultry Production, 15, 27-29.

[9] Brake, J., Balnave, D. and Dibner, J.J. (1994) Optimum Dietary Arginine: Lysine Ratio for Broiler Chickens Is Altered during Heat Stress in Association with Changes in Intestinal Uptake and Dietary Sodium Chloride. British Poultry Science, 39, 639-647. https://doi.org/10.1080/00071669888511

[10] Popoola, I. O. and Iyayi, E. A. (2018) Response of Heat-Stressed Broiler Chicks to Varying Dietary Electrolyte Balance at Pre-Starter and Starter Phases. Proceeding of 43rd Annual Conference of the Nigerian Society for Animal Production, FUT Owerri, 18th-22nd March 2018.

[11] Ganot, A. and Atkinson, E. (1883) Elementary Treatise on Physics Experimental and Applied for the Use of Colleges and Schools. William and Wood, New York, 272-273.

[12] Lacroix, R.L., Keeney, D.R. and Welsh, L.M. (1970) Potentiometric Titration of Chloride in Plant Tissue Extracts Using the Chloride Ion Electrode. Communications in Soil Science and Plant Analysis, 1, 1-6. https://doi.org/10.1080/00103627009366233

[13] Statistical Analysis System (2012) SAS Users Guide: Statistics. SAS Institute Inc., Cary, NC.

[14] Borges, S.A., Fischer Da Silva, A.V. and Ariki, J. (2003) Dietary Electrolyte Balance for Broiler Chickens under Moderately High Ambient Temperatures and Relative Humidities. Poultry Science, 82, 301-308. https://doi.org/10.1093/ps/82.2.301

[15] Johnson, R.J. and Karunajeewa, H. (1985) The Effects of Dietary Minerals and Electrolytes on the Growth and Physiology of the Young Chick. The Journal of Nutrition, 115, 1680-1690. https://doi.org/10.1093/jn/115.12.1680

[16] Hulan, H.W., Simons, P.C.M. and Van Schagen, P.J.W. (1987) Effect of Altering the Cation Anion $(\mathrm{Na}+\mathrm{KCl})$ and Calcium Content of the Diet on General Performance and Incidence of Tibial Dyschondroplasia of Broiler Chickens Housed in Batteries. 
Nutrition Reports International, 33, 397-408.

[17] Rondon, O.O., Murakami, A.E., Moreira, I., Macari, M. and Furlan, A.C. (2001) Sodium and Chloride Requirements of Growing Broiler Chickens Fed Corn-Soybean Diets (One to Twenty-One Days of Age). Poultry Science, 80, 592-598. https://doi.org/10.1093/ps/80.5.592

[18] Murakami, A.E., Rondon, E.O.O., Pereira, M.S., Scapinello, C. and Martins, E.N. (2001) Sodium and Chloride Requirements of Growing Broiler Chickens (Twenty-One to Forty-Two Days of Age) Fed Cornsoybean Diets. Poultry Science, 80, 289-294. https://doi.org/10.1093/ps/80.3.289

[19] Mongin, P. (1981) Recent Advances in Dietary Cation-Anion Balance: Applications in Poultry. Proceedings of the Nutrition Society, 40, 285-294. https://doi.org/10.1079/PNS19810045

[20] Rondon, O.O., Murakami, A.E. and Furlan, A.C. (2000) Exigencias nutricionais de sodio a cloro a estimativa do melhor balango eletrolitico da ragao para frangos de corte na fase preinicial (17 Dias de Idade). Revista Brasileira de Zootecnia, 29, 1162-1166. https://doi.org/10.1590/S1516-35982000000400029

[21] Deyhim, F. and Teeter, R.G. (1991) Research Note: Sodium and Potassium Chloride Drinking Water Supplementation on Acid-Base Balance and Plasma Corticosterone in Broilers Reared in Thermoneutral and Heat-Distressed Environments. Poultry Science, 70, 2551-2553. https://doi.org/10.3382/ps.0702551

[22] Belay, T. and Teeter, R.G. (1993) Broiler Water Balance and Thermobalance during Thermoneutral and High Ambient Temperature Exposure. Poultry Science, 72, 116-124. https://doi.org/10.3382/ps.0720116

[23] Borges, S.A. (1997) Suplementacao de cloreto de potassio e bicarbonato de sodio para frangos de corte durante o verao. Dissertacao de Mestrado, Unesp, Jaboticabal, Brazil.

[24] Borges, S.A. (2001) Balanco eletrolitico e sua interrelacao com o equilibrio acidobase em frangos de corte submetidos a estresse calorico. Jaboticabal. Tese (Doutorado em Zootecnia) curso de posgraduacao em Zootecnia, Universidade Estadual Paulista, São Paulo, 97. 